\title{
PEMBERIAN EKSTRAK ETANOL KUBIS UNGU (Brassica oleraceae L.) MENURUNKAN KADAR MALONDIALDEHID DAN JUMLAH MAKROFAG JARINGAN PARU TIKUS YANG TERPAPAR ASAP ROKOK
}

\author{
(ADMINISTRATION OF PURPLE CABBAGE ETHANOL EXTRACT (Brassica oleraceae L.) \\ REDUCING MALONDIALDEHID LEVELS AND NUMBER OF MACROFAGS OF RAT LUNG \\ WHICH ARE EXPOSED TO CIGARETTE SMOKE)
}

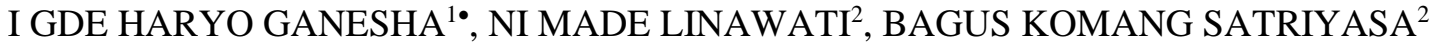 \\ ${ }^{1}$ Program Studi Magister Biomedik, Fakultas Kedokteran Universitas Udayana \\ ${ }^{2}$ Departemen Histologi, Fakultas Kedokteran, Universitas Udayana
}

\begin{abstract}
Abstrak: Asap rokok merupakan polutan bagi manusia dan lingkungan. Asap rokok mengandung senyawa radikal bebas yang akan menyebabkan stres oksidatif. Pada kondisi stres oksidatif, radikal bebas menyebabkan peroksidasi lipid membran sel dan merusak organisasi membran sel ditandai dengan peningkatan kadar MDA dan peningkatan jumlah makrofag pada paru. Penggunaan antioksidan dari tumbuhan seperti kubis ungu yang mengandung senyawa flavonoid menjadi salah satu alternative untuk menetralisir terjadinya peningkatan malondialdehyde (MDA) dan peningkatan jumlah makrofag pada paru. Penelitian ini adalah penelitian eksperimental dengan menggunakan post-test control group design yang menggunakan 36 ekor tikus putih (Rattus norvegicus) jantan, berumur 2-3 bulan, dengan berat badan 200 gram. Hasil penelitian menunjukan bahwa rerata jumlah rerata kadar malondialdehyde (MDA) pada kelompok (P0) adalah 4,575 $\pm 2,034$ dan pada kelompok (P1) adalah 2,451 $\pm 1,036$ ( $\mathrm{p}<0,001)$. Sedangkan untuk rerata jumlah makrofag pada kelompok (P0)

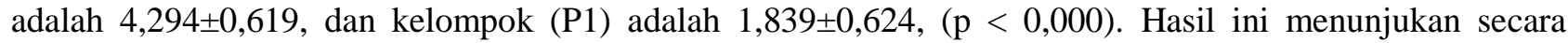
bermakna bahwa pemberian ekstrak kubis ungu (Brassica oleraceavar. capitata L.) pada tikus galur wistar (Rattus norvegicus) jantan dapat menurunkan kadar malondialdehyde (MDA) dan dapat menurunkan jumlah makrofag pada paru. Berdasarkan hasil penelitian ini dapat disimpulkan bahwa pemberian ekstrak etanol kubis ungu pada tikus galur wistar jantan dapat menurunkan kadar malondialdehyde (MDA) dan dapat menurunkan jumlah makrofag pada paru. tikus galur wistar jantan yang dipaparkan asap rokok sebanyak 3 batang selama 14 hari.
\end{abstract}

Kata Kunci: Rokok, Kubis Ungu, malondialdehyde (MDA), Makrofag Paru.

Abstract: Cigarette smoke is a pollutant for humans and the environment. Cigarette smoke contains free radical compounds that will lead to oxidative stress. Under oxidative stress condition, the free radicals cause lipid peroxidation of cell membranes and damage the cell membranes organization characterized by increased levels of MDA and the number of macrophages in the lungs. The use of antioxidants from plants such as purple cabbage containing flavonoid compounds is an alternative way to neutralize the increase of malondialdehyde (MDA) and the number of macrophages in the lungs. An experimental study using a post-test control group design was conducted among 36 white male rats (Rattus norvegicus), aged 2-3 months, with a bodyweight of 200 grams. The results showed that the mean level of malondialdehyde (MDA) in the group (P0) was $4.575 \pm$ 2.034 , and in the group (P1) was $2.451 \pm 1.036(\mathrm{p}<0.001)$. Whereas the mean number of macrophages in the group (P0) was 4.294 \pm 0.619 , and the group (P1) was $1.839 \pm 0.624,(\mathrm{p}<0.000)$. These results show a statistically significant of purple cabbage extract administration (Brassica oleraceae var Capitata L.) in male Wistar strain rats (Rattus norvegicus) in reducing the levels of malondialdehyde (MDA) and the number of macrophages in the lungs. Based on the recent findings, it can be concluded that the administration of purple cabbage ethanol extract in male Wistar rats can reduce the levels of malondialdehyde (MDA) and the number of macrophages in the lungs male Wistar strain rats exposed to 3 cigarettes for 14 days.

Keywords: Cigarette, Purple Cabbage, Malondialdehyde (MDA), Lung Macrophages

\section{PENDAHULUAN}

Rokok merupakan penyumbang radikal bebas terbesar terkait dengan berbagai patologi yang ditimbulkannya. Asap rokok merupakan campuran senyawa yang mengandung lebih dari
4800 bahan kimia dimana 200 lebih bahan bersifat racun dan 40 lebih bahan bersifat karsinogen yang menyebabkan kematian, (Geiss dan Kotzias, 2007). Komponen gas asap rokok adalah karbon monoksida, amoniak, asam hidrosianat, nitrogen oksida dan formalin. Partikelnya berupa tar, indol

• Corresponding author's email: gdeganesha@gmail.com 
nikotin, karbarzol dan kresol. Zat-zat ini beracun karena menimbulkan efek inflamasi dan radikal bebas, menyebabkan proliferasi dan aktivasi dari fagosit pada paru dan seluruh tubuh yang dapat menurunkan efek antioksidan. Tingginya kadar radikal bebas dalam darah perokok aktif dapat memicu timbulnya berbagai penyakit yang berbahaya bagi tubuh, sehingga hal ini berhubungan dengan timbulnya berbagai penyakit pada seorang perokok,seperti emfisema dan kanker paru. (KPAI, 2009). Organ yang paling berisiko untuk mengalami kerusakan akibat asap rokok adalah paru, karena selalu terpapar asap rokok secara terus menerus (Baneerje, 2008).

Rokok mengandung berbagai bahan kimia antara lain nikotin, tar, dan karbon monoksida (dalam rokok kretek) sedangkan asap rokok mengandung 10 14-16 molekul oksidan antara lain: superoksida, hidrogen peroksida, hidroksil dan peroksil dalam satu hisapan (Yanbaeva et al., 2007). Paparan asap pada perokok aktif maupun pasif, merupakan salah satu faktor utama meningkatnya radikal bebas di dalam tubuh. Mekanisme meningkatnya radikal bebas karena efek langsung asap rokok pada paru yaitu aktivasi sel inflamasi. Proses tersebut akan menghasilkan ROS (reactive oxygen species) erlebih, yang merupakan oksidan utama dalam tubuh (Block et al., 2004).

$$
\text { Peningkatan ROS menyebabkan }
$$

ketidakseimbangan oksidan dan antioksidan dalam tubuh yang menyebabkan stres oksidatif dan sangat potensial menyebabkan kerusakan sel. Radikal bebas bereaksi dengan lemak, protein, dan asam nukleat seluler, sehingga terjadi kerusakan lokal dan disfungsi organ (Rahman, 2006). Stres oksidatif menginduksi peroksidasi membran lipid sehingga dapat menimbulkan kerusakan yang akan menyebabkan perubahan struktur biologis kadar cairan membran, serta dapat menonaktifkan ikatan membran dengan reseptor atau enzim yang dapat mengganggu fungsi normal sel (Dalle-Donne et al.,2006). Lipid merupakan biomolekul yang rentan terhadap serangan radikal bebas. Mekanisme kerusakan sel atau jaringan akibat serangan radikal bebas yang paling awal diketahui dan terbanyak diteliti adalah peroksidasi lipid. Peroksidasi lipid paling banyak terjadi di membran sel, terutama Polysaturated Fatty Acid (PUFA) yang merupakan komponen penting penyusun membran sel (Kumar et al., 2009).

Malondialdehyde (MDA) adalah salah satu senyawa yang terbentuk sebagai produk akhir proses peroksidasi lipid, larut dan dapat dijumpai dalam darah (Setiawan, 2007). Peningkatan stres oksidatif sesuai dengan peningkatan pembentukan Malondialdehyde (MDA). Pengukuran kadar malondialdehyde (MDA) serum dapat dilakukan dengan Test Thio Barbituric Acid-Reactive Substance (TBARS) yang berdasar pemeriksaan reaksi spektrofotometrik (Del Rio et al., 2005). Adanya radikal bebas yang berasal dari paparan asap rokok, maka akan terjadi proses peroksidasi lipid pada jaringan paru. Proses peroksidasi lipid ini, akan menghasilkan endoperoksida yang membentuk produk akhir senyawa malondialdehyde (MDA). Jumlah radikal bebas yang berlebih mengakibatkan peningkatan proses peroksidasi lipid sehingga produk malondialdehyde (MDA) juga meningkat (Murray, 2009). Bahan toksik ini akan berikatan dengan protein, menghancurkan integritas membran sel, merusak aktivitas transport protein, membuat kolaps ion gradient, dan akhirnya memicu kematian sel (Nurwati, 2007).

Tubuh manusia memerlukan perlindungan terhadap kerusakan akibat radikal bebas, zat yang dapat menetralkan radikal bebas itu dapat berupa antioksidan. Antioksidan merupakan suatu zat yang terdapat di dalam sel baik pada membran sel maupun di dalam ekstrasel yang mempunyai sifat menghambat atau mencegah kemunduran, kerusakan atau kehancuran sel akibat reaksi oksidasi. Antioksidan dibagi menjadi dua, yaitu antioksidan Enzimatik (endogen, yang terdapat di dalam tubuh) dan antioksidan non enzimatis (eksogen). Zat antioksidan non enzimatis ini dapat berupa vitamin $\mathrm{A}$, vitamin $\mathrm{C}$, vitamin $\mathrm{E}$, beta karoten, dan lain-lain (Nurwati, 2007). Contoh antioksidan seperti senyawa fenol atau polifenon yang dapat berupa golongan flavonoid. Sering dengan perkembangan ilmu pengetahuan, penelitian tentang buah, sayuran dan tanaman yang mengandung antioksidan telah banyak dilakukan contohnya kubis ungu.

Kubis Ungu (Brassica oleracea var. capitata L.) merupakan salah satu tanaman genus Brasica yang banyak terdapat diIndonesia. Kubis ungu mempunyai banyak manfaat karena mempunyai banyak kandungan antara lain vitamin $\mathrm{A}, \mathrm{B}, \mathrm{C}$ dan $\mathrm{E}$, mineral kalium, kalsium, fosfor, natrium dan besi, sulforafan serta mengandung flavonoid (Lin dkk, 2008). Flavonoid mampu menghentikan reaksi radikal bebas dengan menyumbangkan hidrogen atau elektron pada radikal bebas dan menstabilkannya. Senyawa antioksidan dalam kubis ungu dapat diperoleh dengan cara ekstraksi. Dalam proses ekstraksi suatu bahan tanaman, banyak faktor yang dapat 
mempengaruhi kandungan senyawa hasil ekstraksi diantaranya: jenis pelarut, konsentrasi pelarut, metode ekstraksi dan suhu yang digunakan untuk ekstraksi.

Berdasarkan penetilian terdahulu yang menunjukan bahwa pada kubis ungu terdapat senyawa fenol dan flavonoid yang dapat berfungsi sebagai antioksidan serta beberapa penelitian yang ekstak kubis ungu, dengan berbagai pelarut lain, dapat menurunkan kadar MDA tikus yang diberikan stres oksidatif. Namun belum ada penelitian tentang pemberian ekstrak etanol kubis ungu menurunkan kadar MDA dan kondisi magrofag jaringan paru tikus yang dipapar asap rokok sehingga diperlukan penelitian untuk mengetahui pemberian ekstrak etanol kubis ungu menurunkan kadar MDA dan gambaran magrofag jaringan paru tikus yang dipapar asap rokok.

\section{METODE PENELITIAN}

Jenis penelitian yang dilakukan adalah penelitian eksperimental laboratories, dengan nomor surat keterangan kelaikan etik (Ethical Clearance): 2067/UN14.2.2.VII.14/LP/2019. Rancangan penelitian ini menggunakan the posttest only control group design.Pengumpulan data hanya dilakukan setelah masing masing kelompok mendapat perlakuan. Penelitian dilakukan di Laboratorium Biomedik Fakultas Kedokteran Universitas Udayana. Waktu Penelitian kurang lebih selama 6 bulan. Mulai dari April sampai dengan Agustus 2019. Subjek yang digunakan dalam penelitian ini adalah tikus putih (Rattus norvegicus) galur wistar yang memenuhi kriteria inklusi dan drop out. Kriteria Inklusi subjek penelitian yang diinkusi dalam penelitian ini harus memenuhi kriteria inklusi sebagai berikut: Tikus jantan uistar sehat, umur 2-3 bulan, berat $\pm 200 \mathrm{~g}$. Kriteria ekslusi subjek penelitian yang diekslusi dari populasi sampel adalah sebagai berikut: Tikus hiperaktif, tikus yang sakit dalam masa penelitian. Kriteris Drop Out subjek penelitian yang di drop out dari populasi sampel adalah sebagai berikut: Tikus mati saat penelitian dan sebelum tiba waktu pengambilan hasil. Teknik penentuan sampel penelitian dilakukan dengan cara berikut: Dari populasi tikus jantan diadakan pemilihan sampel berdasarkan kriteria inklusi, jumlah sampel yang telah memenuhi syarat diambil secara random untuk mendapatkan jumlah sampel, sampel telah dipilih kemudian dibagi menjadi 2 kelompok yaitu kelompok kontrol dan kelompok perlakuan. Dilakukan penelusuran pada karakteristik subjek meliputi jenis latihan maksimal, jenis hewan coba, umur, jenis kelamin, berat badan, makanan dan minuman, serta kondisi lingkungan kandang. Analisis data dilakukan dengan bantuan perangkat lunak SPSS versi 16.

\section{HASIL}

Hasil penelitian menunjukan bahwa terdapat peningkatan rerata kadar MDA dan jumlah makrofag pada tikus wistar jantan yang diberikan paparan asap rokok tanpa memberikan ekstrak yaitu kelompok (P0) memiliki rerata kadar MDA $(4,575 \pm 2,034)$ dan memiliki rerata jumlah makrofag $(4,294 \pm 0,619)$ dibandingkan dengan kelompok (P1) terdapat penurunan kadar MDA dan jumlah makropag pada tikus wistar jantan yang diberikan paparan asap rokok dengan pemberian ekstrak kubis ungu selama 14 hari, yaitu memiliki rerata kadar MDA $(2,451 \pm 1,036)$, dan memiliki rerata jumlah makrofag $(1,839 \pm 0,624)$.

Tabel 1. Hasil Analisa Deskriptif Data Variabel Penelitian

\begin{tabular}{lllc}
\hline \multicolumn{1}{c}{ Variabel } & \multicolumn{1}{c}{ Kelompok } & Rerata & SD \\
\hline Kadar & Merokok & & \\
MDA & $\begin{array}{l}\text { tanpa ekstrak } \\
(\mu \mathrm{M})\end{array}$ & 4,57517 & 2,034760 \\
& $(\mathrm{P} 0)$ & & \\
& & & \\
& $\begin{array}{l}\text { Merokok + } \\
\text { Ekstrak }\end{array}$ & 2,45139 & 1,036779 \\
& $\begin{array}{l}\text { Kubis Ungu } \\
(\mathrm{P} 1)\end{array}$ & & \\
\hline Jaringan & Kelompok P0 & 4,294 & 0,6197 \\
Makrofag & Kelompok PI & 1,839 & 0,6242 \\
$\begin{array}{l}\text { Paru } \\
\text { (sel) }\end{array}$ & & & \\
\hline
\end{tabular}

Variable kadar MDA dan jumlah makrofag pada masing masing kelompok (P0) dan (P1) diuji distribusinya dengan menggunakan uji ShapiroWilk. Signifikasi hasil analisis data berpedoman 
pada tingkat kepercayaan $95 \%(\alpha=0,05)$. Hasilnya menunjukan bahwa data estimasi kadar MDA dan jumlah makrofag pada masing-masing kelompok berdistribusi normal $(\mathrm{p}>0,05)$ sehingga asumsi pertama analisis data penelitian telah terpenuhi yang disajikan pada tabel 2 di bawah ini.

Tabel 2. Hasil Uji Normalitas Data Antar Kelompok

\begin{tabular}{lcccc}
\hline \multicolumn{1}{c}{ Variabel } & Kelompok & $\mathrm{n}$ & $\mathrm{P}$ & Keterangan \\
\hline $\begin{array}{l}\text { Kadar MDA } \\
(\mu \mathrm{M})\end{array}$ & $\begin{array}{c}\text { Merokok Tanpa } \\
\text { Ekstrak (P0) }\end{array}$ & 18 & 0,230 & Normal \\
& $\begin{array}{c}\text { Merokok + } \\
\text { Ekstrak Kubis } \\
\text { Ungu (P1) }\end{array}$ & 18 & 0,083 & Normal \\
\hline $\begin{array}{l}\text { Jaringan } \\
\begin{array}{l}\text { Makrofag } \\
\text { (sel) }\end{array}\end{array}$ & Kelompok P0 & 18 & 0,458 & Normal \\
\hline
\end{tabular}

Variable kadar MDA dan jumlah makrofag pada masing masing kelompok (P0) dan (P1) diuji distribusinya dengan menggunakan uji Levene's statistic. Hasilnya menunjukan bahwa hanya varian data kelompok kadar MDA tidak homogen yaitu $(0,001)(\mathrm{p}<0,05)$, sedangkan pada jumlah makrofag homogen yaitu $(0,715)(\mathrm{p}>0,05)$.

Tabel 3. Hasil Uji Homogenitas Data Antar Kelompok

\begin{tabular}{|c|c|c|c|}
\hline Variabel & $\mathrm{N}$ & $\mathrm{P}$ & Keterangan \\
\hline $\begin{array}{l}\text { Kadar MDA } \\
(\mu \mathrm{M})\end{array}$ & 36 & 0,001 & Tidak Homogen \\
\hline $\begin{array}{l}\text { Jaringan Makrofag } \\
\text { Paru } \\
\text { (sel) }\end{array}$ & 36 & 0,715 & Homogen \\
\hline
\end{tabular}

Analisis komparabilitas bertujuan untuk membandingkan rerata estimasi kadar MDA antara kelompok tikus witar jantan yang diberikan paparan asap rokok tanpa pemberian ekstrak (P0) dan tikus wistar jantan yang diberikan paparan asap rokok dengan pemberian ekstrak kubis ungu (P1) selama 14 hari. Analisa kemaknaan untuk kedua variable diuji dengan Independent Sampel T-test.

Rerata jumlah kadar MDA pada kelompok (P0) setelah diberikan paparan asap rokok tanpa pemberian ekstrak selama 14 hari adalah
4,575 $\pm 2,034$, sedangkan pada kelompok (P1) yang diberikan paparan asap rokok dengan pemberian ekstrak kubis ungu memliki nilai rerata $2,451 \pm 1,036$. Analisis kemaknaa dengan Independent Sampel T-test menunjukan bahwa nilai $\mathrm{t}=3,946$ dan nilai $\mathrm{p}=0,001$. Hal ini menunjukan bahwa kelompok perlakuan (P1) memiliki rerata jumlah kadar MDA yang lebih rendah secara bermakna dibandingkan dengan kelompok control $(\mathrm{P} 0)$ berarti $(\mathrm{p}<0,05)$.

Tabel 4. Hasil Uji Independent Sampel T-test Kadar MDA Antar Kelompok

\begin{tabular}{cccc}
\hline Kelompok Subjek & $\mathrm{N}$ & $\begin{array}{c}\text { Rerata Jumlah Kadar } \\
\text { MDA }(\mu \mathrm{M})\end{array}$ & $\mathrm{T}$ \\
\hline $\begin{array}{c}\text { Merokok Tanpa } \\
\text { Ekstrak (P0) }\end{array}$ & 18 & $4,575 \pm 2,034$ & \\
Merokok + & 18 & & 3,946 \\
Ekstrak Kubis & & $2,451 \pm 1,036$ & \\
$\quad$ Ungu (P1) & & & \\
\hline
\end{tabular}

Rerata jumlah makrofag pada kelompok (P0) setelah diberikan paparan asap rokok tanpa pemberian ekstrak selama 14 hari adalah $4,294 \pm 0,619$, sedangkan pada kelompok (P1) yang diberikan paparan asap rokok dengan pemberian ekstrak kubis ungu memliki nilai rerata $1,839 \pm 0,624$. Analisis kemaknaa dengan Independent Sampel T-test menunjukan bahwa nilai $\mathrm{t}=11,844$ dan nilai $\mathrm{p}=0,000$. Hal ini menunjukan bahwa kelompok perlakuan (P1) 
memiliki rerata jumlah makrofag yang lebih rendah secara bermakna dibandingkan dengan kelompok kontrol $(\mathrm{P} 0)$ berarti $(\mathrm{p}<0,05)$.

Tabel 5. Hasil Uji Independent Sampel T-test

Makropag Jaringan Paru Antar Kelompok

\begin{tabular}{ccccc}
\hline $\begin{array}{c}\text { Kelompok } \\
\text { Subjek }\end{array}$ & $\mathrm{n}$ & $\begin{array}{c}\text { Rerata Jumlah } \\
\text { Makropag } \\
\text { Jaringan Paru } \\
\text { (sel) }\end{array}$ & $\mathrm{t}$ & $\mathrm{P}$ \\
& & \\
\hline
\end{tabular}

\begin{tabular}{lcccc}
$\begin{array}{l}\text { Kelompok } \\
\quad 18\end{array}$ & $(4,294 \pm 0,619)$ & & \\
$\quad$ P0 & 18 & $(1,839 \pm 0,624)$ & 11,844 & 0,000 \\
Kelompok & & & & \\
P1 & & & & \\
\hline
\end{tabular}

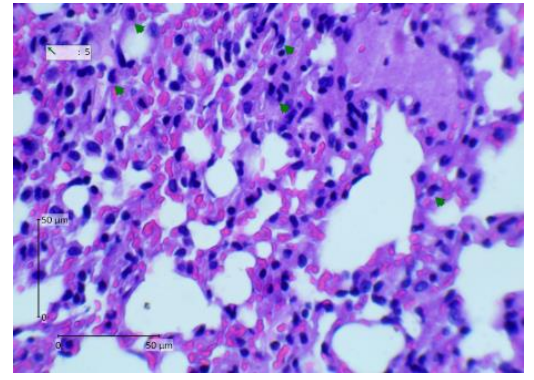

Gambar 1 jaringan makropag paru control.

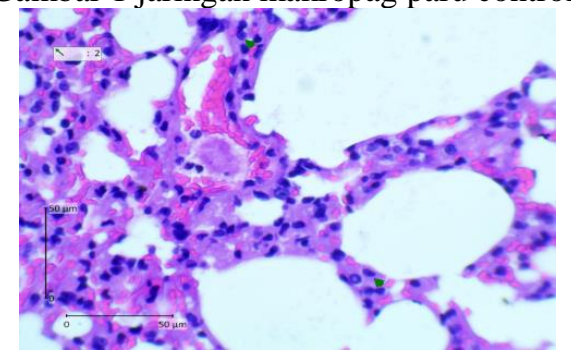

Gambar 2 jaringan makropag paru perlakuan

\section{PEMBAHASAN}

\section{Pemberian Ekstrak Kubis Ungu Dengan} Pemaparan Asap Rokok Terhadap Kadar MDA. Hasil penelitian menunjukkan pemaparan asap rokok menyebabkan peningkatan kadar MDA. Pada kelompok control (P0) setelah diberikan paparan asap rokok tanpa pemberian ekstrak selama 14 hari memiliki rerata kadar MDA tertinggi yaitu $4,575 \pm 2,034$, yang berbeda nyata dengan kelompok perlakuan (P1) yang diberikan paparan asap rokok dengan pemberian ekstrak kubis ungu memliki nilai rerata lebih rendah $2,451 \pm 1,036$. Pada keadaan normal, radikal bebas terbentuk di dalam tubuh sangat lambat dan perlahan. Pada saat radikal bebas meningkat melebihi kemampuan pertahanan endogen, maka akan terjadi ketidakseimbangan antara jumlah radikal bebas dengan antioksidan endogen, sehingga terjadilah ketidakstabilan (stres) oksidatif. Stres oksidatif menyebabkan peroksidasi lipid yang berlebihan. Hasil dari peroksidasi lipid adalah MDA, sehingga meningkatnya peroksidasi lipid dapat menyebabkan kadar MDA dalam tubuh meningkat (Winarsi, 2007). Paparan asap rokok dapat menyebabkan kerusakan pada organ paru-paru. Rusaknya paru-paru sebagai target utama yang langsung terkena asap rokok dapat dijelaskan dengan adanya paparan agen kimia di dalam asap rokok. Namun, efek yang menyebabkan penyakit kronis pada system organ lain kemungkinan adalah hasil pajanan secara tidak langsung (Yanbaeva et al., 2007).

Fase gas asap rokok terbukti menginisiasi autooksidasi in vitro dari PUFA sehingga terjadi peroksidasi lipid. Fase gas asap rokok dapat berisi hingga 1014 radikal bebas dan zat-zat reaktif per kepulan asap rokok. Radikal bebas dan oksidan yang terdapat pada fase gas asap rokok memiliki waktu paruh pendek, namun senyawa tersebut dapat memasuki aliran darah dan menyebabkan kerusakan oksidatif makromolekul (Swan \& Lessov, 2007). Fase gas asap rokok juga mengandung aldehida jenuh dan tak jenuh yang lebih stabil daripada radikal bebas dan hidrogen peroksida. Senyawa tersebut dapat masuk ke dalam aliran darah menghasilkan ROS melalui interaksi dengan enzim NADPH. Akibatnya, jaringan yang jauh dari paru-paru juga dapat mengalami peningkatan stres oksidatif (Tostes et al., 2008). Hasil penelitian ini didukung oleh penelitian yang dilakukan oleh Adyttia et al. (2014) menunjukkan bahwa pemberian asap rokok (3 batang/hari) menggunakan mesin epavorator pada tikus selama 14 hari mengakibatkan peningkatan kadar MDA. Penelitian Muhammad (2009), melaporkan bahwa pemberian asap rokok (4 batang/hari selama 30 hari) pada tikus menunjukkan adanya kenaikan kadar MDA dan penurunan aktivitas SOD.

Fase partikel asap rokok mengandung kompleks hidrokarbon yang akan bereaksi dengan nitrogen oksida (NO) dan membentuk senyawa radikal lain. NO yang terdapat pada asap rokok dapat menginisiasi PUFA dan mengakibatkan pembentukan peroksidasi lipid. Fase partikel asap rokok memiliki waktu paruh lebih lama daripada fase gas. Fase partikel mengandung ion logam yang dapat menghasilkan radikal hidroksil dari hidrogen peroksida. Radikal tersebut dapat menembus membran sel dan dapat menginduksi stres oksidatif (Wulandari, 2016). Radikal bebas akan mengikat molekul-molekul yang paling rentan pada membran sel seperti PUFA. Jembatan metilen pada PUFA merupakan sasaran utama radikal bebas 
yang akan membentuk radikal alkil, peroksil dan alkoksil (Wulandari, 2016).

Kadar MDA pada kelompok perlakuan ekstrak kubis ungu mengalami penurunan. Hasil skrining fitokimia pada simplisia dan ekstrak etanol kubis ungu yang dilakukan di Pusat Penelitian Biologi-LIPI Bogor menunjukan bahwa ekstrak kubis ungu mengandung senyawa flavonoid, glikosida, dan antrakinon (Harahap, 2016). Tanaman yang mengandung senyawa flavonoid telah terbukti mempunyai aktivitas antioksidan, (Wulandari, 2016). Flavonoid berperan sebagai antioksidan dengan cara mengkelat logam, berada dalam bentuk glukosida (memiliki rantai samping glukosa) atau dalam bentuk bebas yang disebut aglikon. Mekanisme flavonoid dapat meredam efek buruk radikal bebas, dengan menghambat peroksidasi lipid melalui aktivasi peroksidase. Flavonoid yang diisolasi dari kubis ungu dapat melindungi membran phospholipid FUPA dengan menyumbangkan atau memberikan salah satu ion Hidrogennya $(\mathrm{H}+)$ kepada peroksil lipid radikal ( LOO*). LOO* merupakan hasil reaksi $\mathrm{HO}^{*}$ pada proses peroksidasi lipid rekasi serangan $\mathrm{HO}^{*}$ terhadap PUFA (PolyUnsaturated Fatty Acid / asam lemak tak jenuh jamak rantai panjang) Pemberian $\mathrm{H}^{*}$ oleh suatu antioksidan dapat menghentikan reaksireaksi radikal selanjutnya sehingga menjadikan radikal yang kurang reaktif (Hamid, 2010). serta meningkatkan ekspresi gen antioksidan endogen melalui aktivasi nuclear factor erythroid 2 related factor 2 (Nrf2) dengan cara mengaktifkan ekstracelular signal regulated protein kinase (ERK), c-jun n-terminal kinase (JNK) dan p38 yang merupakan kinase berperan dalam fosfolrisasi nuclear factor erythroid 2 related factor 2 (Nrf2) dan meningkatkan kadar nuclear factor erythroid 2 related factor 2 (Nrf2) disitoplasma selanjutnya nuclear factor erythroid 2 related factor 2 (Nrf2) terakumulasi di sitoplasma dapat bertranslokasi kedalam nucleus dan berikatan dengan antioksidan responsive elemen (ARE) sehingga mengaktifkan transkripsi gen antioksidan endogen seperti SOD, HO-1 dan NQO1 sehingga terjadi peningkatan dalam sintesis enzim SOD (Sumardika dan Jawi, 2012).

Pemberian Ekstrak Kubis Ungu Dengan Pemaparan Asap Rokok Terhadap Makropag Paru Tikus. Pengamatan terhadap kerusakan paru menunjukkan persentase paling tinggi Pada kelompok control (P0) setelah diberikan paparan asap rokok tanpa pemberian ekstrak selama 14 hari memiliki rerata jumlah makropag tertinggi yaitu $4,294 \pm 0,619$, yang berbeda nyata dengan kelompok perlakuan (P1) yang diberikan paparan asap rokok dengan pemberian ekstrak kubis ungu memliki nilai rerata lebih rendah 1,839 $\pm 0,624$. Kelompok kontrol yang hanya diberikan asap rokok tanpa diberikan ekstrak menunjukkan kerusakan paling tinggi. Hasil ini sesuai dengan penelitian Kristina, (2014). Proses pemaparan dilakukan dalam smoking chamber. Proses pemaparan dilakukan setiap pagi menggunakan 3 batang rokok. Pemaparan dilakukan selama 14 hari didalam smoking chamber yang terbuat dari plastik ukuran 38,5 x 28,5 x 22,5 cm dilengkapi dengan ventilasi, dua buah air pump dan tempat pembakaran rokok. Satu jam setelah pemaparan asap rokok, tikus diberi ektstrak etanol daun buasbuas sesuai variasi dosis. Radikal bebas yang berasal asap rokok dapat mengakibatkan terjadinya kerusakan pada paru melalui mekanisme asap rokok menyebabkan terjadinya stress oksidatif yang merusak alveolus paru (Kristina, 2014).

Senyawa flavonoid berfungsi sebagai inhibitor protease. Sehingga ketika asap rokok masuk kedalam tubuh yang memicu proses inflamasi yang menyebabkan adanya ketidakseimbangan antara antiprotese dengan protease yang terdapat pada jaringan alveolar menyebabkan degradasi jaringan paru. Flavonoid ini akan menghambat kerja dari protease untuk mengelastisitas paru sehingga jaringan paru akan mengalami perbaikan dari adanya pelebaran lumen alveolus. Flavonoid sebagai antioksidan dalam menurunkan derajat kerusakan paru dapat mengurangi pelepasan sel radang seperti alveolar makrofag dan neutrophil (Manuella et al., 2011).Terjadinya kerusakan berupa infiltrasi sel radang ditimbulkan karena respon normal proses biokimia internal maupun eksternal yang menghasilkan suatu radikal bebas endogen yang pada akhirnya dapat menimbulkan terjadinya suatu inflamasi yang ditunjukkan dengan adanya leukosit terutama neutrofil pada mikrovaskuler pulmonal dinding alveolus. Adanya penumpukan sel radang pada dinding alveolus menyebabkan terjadinya penebalan pada struktur dinding alveolus (Kristina, 2014).

\section{SIMPULAN}

Pemberian ekstrak etanol kubis ungu (Brassica oleraceavar. capitata L.) dapat menurunkan kadar malondialdehyded (MDA) pada tikus galur wistar jantan (Rattus norvegicus) yang dipapar asap rokok 3 batang selama 14 hari. Pemberian ekstrak etanol kubis ungu (Brassica oleraceavar. capitata L.) secara statistic dapat 
menurunkan jumlah makrofag paru pada tikus galur wistar jantan (Rattus norvegicus) yang dipapar asap rokok 3 batang selama 14 hari.

\section{UCAPAN TERIMAKASIH}

Penulis mengucapkan terimakasih kepada seluruh dosen dan rekan-rekan yang telah membimbing dan membantu selama penelitian berlangsung.

\section{DAFTAR PUSTAKA}

Adyttia, A., Untari, E.K., Wahdaningsih, S. 2014. Efek Ekstrak Etanol daun Premna cordifolia terhadap malondialdehydeda tikus yang dipapar asap rokok. J Pharm Sie 1(2):104115

Banerjee S. 2008. Cellular and molecular mechanisms of cigarette smoke-induced lung damage and prevention by vitamin $\mathrm{c}$. Journal of inflammation. 5:21

Budilaksono, W., Wahdaningsih, S., dan Fahrurroji, A. 2014. Uji Aktivitas Antioksidan Fraksi N-Heksana Kulit Buah Naga Merah Menggunakan Metode DPPH (1,1 - Difenil - 2 - Pikrilhidrazil), Jurnal Mahasiswa Farmasi Fakultas Kedokteran UNTAN, vol. 1 no. 1.

Crofton, J., Simpson, D. 2002. Tembakau Ancaman Global. Jakarta: PT Elex Media Komputindo

Geiss, O and D. Kotzias. 2007. Tobacco, cigarettes, and cigarettesmoke. Overview. Institute for Health and Consumer Protection. Europian Commission, London.

Gondodiputro, Sharon. 2007. Bahaya Tembakau dan Bentuk-Bentuk Sediaan Tembakau. Bagian Ilmu Kesehatan Masyarakat, Fakultas Kedokteran Universitas Padjajaran. Bandung.

Halliwell, B. and Gutteridge, J.M.C. 2007. Free Radicals in Biology and Medicine. New York: Oxford Univerisy Press.p.19-633.

Hardjadinata, S. 2010. Budi Daya Buah Naga Super Red Secera Organik. Bogor: Penebar Swadaya
Jaffar, R..A., Ridhwan A., Mahmod, N.Z.C., Vasudevan, R. 2009. Proximate Analysis of Dragon Fruit (Hylocereus polyrhizus'. American Journal of Applied Sciences, 6 (7): 1341-1346

Manuella, L., Lopes., Thiago, S., Ferreira., Roberto, S.M.,Resende, A., Porto,L.C., Valenc, S.S. 2011. Mate Tea Ameliorates Emphysema In Cigarette Smoke-Exposed Mice. Experimental Lung Research. JuniOktober. ISSN: 0190-2148. 246-257.

Mardjun, Y. 2012. “Perbandingan Keadaan Tulang Alveolar Antara perokok dan Bukan Perokok" (skripsi). Makassar: Universitas Hasannudin

Marlina, 2016. "Ekstrak Etanol Buah Naga Merah (Hylocereus Polyrhizus) Menurunkan Kadar Malondialdehyde (MDA) Pada Tikus (Rattus Norvegicus) Wistar Jantan Dislipidemia" (tesis). Denpasar: Universitas Udayana

Moriarty, S.E., Shah, J.H., Lynn, M., Jiang, S., Openo, K., Jones, D.P., Sternberg P. Oxidation of glutathione and cysteine in human plasma associated with smoking. Free Radical Biology and Medicine. 2003;35:1582-8

Muchtadi, D. 2013. Antioksidan dan Kiat Sehat di Usia Produktif. Bandung: Penerbit Alfabeta

Murray, R.K. 2006. Metabolism of Xenobiotics. In R.K.Murray, D.K. Granner, \& V.W. Rodwell (Eds), Harper's Illustrated Biochemistry, 27th Edition, (p.633-640). New York: McGraw-Hill.

Nurliyana, R., Syed, Z, I., Mustapha, S.K., Aisyah, M.R, and Kamarul, R.K. Antioxidant Study of Pulps and Peels of Dragon Fruits: A Comparative Study. Internasional Food Research Journal. 2010;17:367-375.

Lodovici, M., Akpan, V., Evangelisti, C., and Dolara P. 2004. Sidestream tobacco smoke as the main predictor of exposure to polycyclic aromatic hydrocarbons. J Applied Toxicology 24: 277-281

Khrisna M.B., Hendrianingtyas M. 2016. Perbedaan Kadar Malondialdehydeda Pada Subyek Bukan Perokok, Perokok Ringan 
dan Sedang-Berat. Jurnal Kedokteran Diponegoro (JKD), v. 5, n. 4, p. 1235-1242 okt. 2016. ISSN 2540-8844. Dapat di akses pada

https://ejournal3.undip.ac.id/index.php/med ico/article/view/14813 >. Diakses pada 28 Januari 2017

Komar, S. 2010." Efek Ekstrak Pomogranat Terhadap Kadar Malondiladehida (MDA) dan Gambaran Mikroskopik Hati Tikus Strain Sprague dawley yang Dipaparkan Asap Rokok" (skripsi). Jakarta: Universitas Islam Negeri Syarif Hidayatullah Jakarta.

Kristanto, D. 2008. Buah Naga Pembudidayaan di Pot dan di Kebun. Surabaya: Penebar Swadaya

Muhammad, I. 2009." Efek antioksidan vitamin C terhadap tikus (Rattus norvegicus) jantan akibat pemaparan asap rokok" (Tesis). Bogor: Sekolah Pascasarjana IPB

Pamungkas, A.D., 2016. "Uji Aktivitas Antioksidan dan Fotoprotektif Fraksi Kloroform Ekstrak Etanolik Kulit Buah Naga Merah (Hylocereus polyrhizus)" (skripsi). Yogyakarta: Universitas Muhammadiyah Yogyakarta.

Pangkahila, W. 2007. Memperlambat Penuaan, Meningkatkan Kualitas Hidup. Anti-Aging Medicine. Cetakan ke-1. Jakarta: Penerbit Buku Kompas.hal. 133-144

Pribadi, Y.S., Sukatiningsih., dan Sari. P. 2014. Formulasi Tablet Effervescent Berbahan Baku Kulit Buah Naga Merah (Hylocereus polyrhizus) dan Buah Salam (Syzygium polyanthum. Berkala Ilmiah PERTANIAN, 1 (4): $86-89$

Rahmawati, M. 2016. "Aktivitas Antioksidan Ekstrak Kulit Buah Naga Merah (Hylocereus polyrhizus) Secara In Vitro" (skripsi). Jember: Universitar Jember

Revel A., N. Raanani., E. Younglai,. J. Xu., R. Han. 2001. Resveratrol,a Natural Aryl Hydrocarbon Receptor Antagonist, Protect Sperm from DNA Damage and Apoptosis Caused by Benzo(a)Pyrene. Reproductive Toxicology15: $479-486$
Rupinder K. 2014. Environmental tobacco smoke (ETS) - A silent killer. Int Journal of Life Science 2(2):179-184

Santoso, P. 2011. "Pemberian Ekstrak Buah Mengkudu (Morinda citrifolia l.) Menurunkan Kadar Malondihaldehida Darah Mencit yang Diinduksi Karbon Tetra Klorida" (tesis). Denpasar: Universitas Udayana

Sari W.M., Wahdaningsih S., Untari E.K. 2014. Efek Fraksi $n$-Heksana Kulit Hylocereus polyrhizus Terhadap Kadar MDA Tikus Stres Oksidatif. Pharmaceutical Sciences and Research (PSR), [S.1.], v. 1, n. 3, p. 154-165, sep. 2016. ISSN 2477-0612. Available at: $<$ http://psr.ui.ac.id/index.php/journal/article /view/3487>. Date accessed: 28 Jan. 2018. doi:10.7454/psr.v1i3.3487.

Shin, H.J., Sohn, H.U., Han, J.H., Park,C.H. 2009. Effect of cigarette filter on the chemical composition and in vitro biological activity of cigarette mainstream smoking. J Food Chem Toxicol 47: 192-197

Simanjuntak K. 2012. Peran Anti Oksidan Flavonoid Untuk Kesehatan" (skripsi), Jakarta: FK UPN

Sitepoe, M. 2000. Kekhususan Rokok Indonesia. Jakarta: PT Grasindo.

Sukmaningsih A.A. 2009. Penurunan Jumlah Spermatosit Pakiten dan Spermatid Tubulus Seminiferus Testis Pada Mencit (Mus musculus L.) Yang Dipaparkan Asap Rokok. Jurnal Biologi 13(2):31-35.1

Sumardika IW \& Jawi IM. 2012. Ekstrak air daun ubijalar ungu memperbaiki profil lipid dan meningkatkan kadar SOD darah tikus yang diberi makanan tinggi kolesterol. Medicina 43(2): 67-71

Sunarjo, I. 2012. "Pemberian Ekstrak Pegagan (Centella asiatica) Menurunkan Kadar MDA Tikus Putih (Wistar) yang Dipapar Asap Rokok" (tesis), Denpasar: Universitas Udayana

Suryohusodo, P. 2000. Oksidan, Antioksidan dan Radikal Bebas, dalam Kapita Selekta Ilmu 
Kedokteran Molekuler.Jakarta: CV. Infomedika: 31-47

Swan, G.E., Lessov. 2007. The effect of tobacco smoke and nicotine on cognition and the brain. Neurophysiol Rev 17: 259-73

Triswanto, SD. 2007. Stop Smoking. Yogyakarta: Progresif Books

Tohomi, KL. 2014. Uji Aktivitas Antioksidan Ekstrak Etanol Daun Buas-buas (premna cordifolia linn.) Terhadap Gambaran Histopatologi Paru-paru Tikus (rattus norvegicus) Wistar Jantan Pasca Paparan Asap Rokok" (skripsi), Pontianak: Program
Studi Farmasi FK Universitas Tanjung Pura Pontianak

Winarsi, H. 2007. Antioksidan Alami dan Radikal Bebas. Yogyakarta: Kaninus, Hal. 13;78-80

Wulandari, E. 2016. "Efek Ekstrak Kulit Buah Rambutan terhadap Kadar MDA dan SOD Tikus yang Dipapar Asap Rokok" (skripsi). Semarang: Universitas Negeri Semarang

Yanbaeva D.G., Dentener M.A., Creutzberg E.C., Wesseling G., and Wouters E.F. 2007. Systemic effect of Smoking. Chest 135(5): $1557-1$ 